\title{
In vitro fertilization and embryo development of Japanese field voles (Microtus montebelli)
}

\author{
T. Wakayama ${ }^{1}$, J. Suto ${ }^{2}$, Y. Matubara ${ }^{2}$, K. Imamura ${ }^{2}$, K. Fukuta ${ }^{2}$, \\ Y. Toyoda ${ }^{3}, M$. Kurohmaru ${ }^{\mathrm{I}}$ and $\mathrm{Y}$. Hayashi ${ }^{\mathrm{I}}$ \\ ${ }^{I}$ Department of Veterinary Anatomy, Faculty of Agriculture, The University of Tokyo, Bunkyo-ku, \\ Tokyo 113, Japan; ${ }^{2}$ National Institute of Animal Health, Tsukuba, Ibaraki 305, Japan; and ${ }^{3}$ Department \\ of Reproductive and Developmental Biology, Institute of Medical Science. The University of Tokyo, \\ Minato-ku, Tokyo 108, Japan
}

\begin{abstract}
Optimal conditions for in vitro fertilization of Japanese field voles (Microtus montebelli) were analysed. The medium used was a modified Krebs-Ringer bicarbonate devised for in vitro fertilization in rats. Ovulated eggs and epididymal spermatozoa were co-incubated in vitro at $37^{\circ} \mathrm{C}$ under $5 \% \mathrm{CO}_{2}$ in air for $6 \mathrm{~h}$, and the eggs were fixed with $2.5 \%(\mathrm{w} / \mathrm{v})$ glutaraldehyde, stained with $0.25 \%(\mathrm{v} / \mathrm{v})$ acetolacmoid and examined for evidence of fertilization at the pronuclear stage. Although the fertilization rate with spermatozoa preincubated at $1-2 \times 10^{8}$ cells $\mathrm{ml}^{-1}$ for $2 \mathrm{~h}$ was very low ( $1-13 \%$ ), it was significantly increased $(43-51 \%, P<0.05)$ when spermatozoa were preincubated at a lower concentration $\left(1-2 \times 10^{7}\right.$ cells $\left.\mathrm{ml}^{-1}\right)$. Furthermore, the fertilization rate was significantly higher with $1 \mathrm{mmol}$ hypotaurine $\mathrm{l}^{-1}(74.0 \%)$ than without hypotaurine $(44.4 \%, P<0.05)$. Fertilization rates of spermatozoa preincubated at $1-2 \times 10^{7}$ cells ml ${ }^{-1}$ for 0.5 or $2 \mathrm{~h}$ were similar $(69.0 \%$ and $73.6 \%$ ), but a longer preincubation $(10 \mathrm{~h})$ resulted in a significantly lower fertilization rate $(56.8 \%, P<0.01)$. Vole spermatozoa preincubated for $2 \mathrm{~h}$ penetrated the zona pellucida $2 \mathrm{~h}$ after insemination, and the sperm heads became decondensed $3 \mathrm{~h}$ after insemination. At $6 \mathrm{~h}$ after insemination, male and female pronuclei were found in most penetrated eggs. When the eggs were left in the fertilization medium without washing and cultured for $96 \mathrm{~h}$ after insemination, they developed to two-cell $(82.6 \%)$, four-cell $(60.9 \%)$, eight-cell $(23.2 \%)$ and morula/blastocyst $(8.7 \%)$ stages in modified Krebs-Ringer bicarbonate supplemented with 1 mmol hypotaurine $1^{-1}$.
\end{abstract}

\section{Introduction}

In vitro fertilization (IVF) techniques contribute to improvement in domestic animal breeding, alleviation of infertility, and conservation of endangered species. Furthermore, IVF permits visual observation of direct interactions between spermatozoa and eggs. Thus, the IVF technique is valuable from many perspectives.

Although the Japanese field vole (Microtus montebelii), a herbivorous rodent, is considered a potential model for herbivorous domestic animals (Kudo and Oki, 1984; Imai and Ogimoto, 1988), its reproductive characteristics have not been thoroughly investigated. Goto et al. (1977) and Goto and Hashizume (1978) reported that voles exhibit a copulatory ovulation and that vaginal smears show no regular pattern. Wakayama et al. $(1993,1994)$ demonstrated that one- and early two-cell vole embryos cannot be cultured to the blastocyst stage, but early two-cell embryos in pyruvate-free M16 or late two-cell embryos in M16 can. They also reported that vole spermatozoa can penetrate the zona pellucida of mouse and hamster eggs in vitro. The present study examined media

Received 4 November 1994 composition, sperm concentration and capacitation time, and the time required to complete fertilization, to clarify optimal conditions for vole IVF. The development of IVF eggs was also evaluated.

\section{Materials and Methods}

\section{Animals}

Japanese field voles were obtained from the National Institute of Animal Health (Japan), where this species had been maintained for over 20 years by outbred mating. The voles were housed under controlled conditions of $14 \mathrm{~h}$ light:10 h dark at $25^{\circ} \mathrm{C}$. They were fed a commercial mouse chow, a herbivore food, (CMF and ZF, respectively, Oriental East Co., Tokyo) and cubed hay. Food and water were available ad libitum.

\section{Culture media}

IVF medium was prepared according to the method of Toyoda and Chang (1974) with modifications as described 
Table 1. Effect of concentrations of Japanese field vole spermatozoa during preincubation and insemination on fertilization in vitro

\begin{tabular}{|c|c|c|c|c|c|c|c|c|}
\hline \multicolumn{2}{|c|}{ Concentration of spermatozoa } & \multirow[b]{2}{*}{$\begin{array}{l}\text { Number } \\
\text { of voles }\end{array}$} & \multirow[b]{2}{*}{$\begin{array}{l}\text { Number } \\
\text { of eggs }\end{array}$} & \multicolumn{3}{|c|}{ Number of fertilized eggs } & \multicolumn{2}{|c|}{ Unfertilized eggs } \\
\hline $\begin{array}{l}\text { Preincubation } \\
\text { (cells } \mathrm{ml}^{-1} \text { ) }\end{array}$ & $\begin{array}{c}\text { IVF } \\
\left(\text { cells } \mathrm{ml}^{-1} \text { ) }\right.\end{array}$ & & & $\begin{array}{c}\text { Total } \\
(\%)\end{array}$ & $\begin{array}{l}\text { Monospermic } \\
\text { eggs }(\%)\end{array}$ & $\begin{array}{l}\text { Polyspermic } \\
\text { eggs (\%) }\end{array}$ & $\begin{array}{c}\text { Parthenogenetic } \\
\text { eggs }(\%)\end{array}$ & $\begin{array}{l}\text { Abnormal } \\
\text { eggs (\%) }\end{array}$ \\
\hline \multirow[t]{2}{*}{$1-2 \times 10^{8}$} & $1 \times 10^{7}$ & 10 & 105 & $1(1.0)^{a}$ & I (1.0) & $O(0)$ & $0(0)$ & $1(1.0)$ \\
\hline & $1 \times 10^{\circ}$ & 10 & 93 & $12(12.9)^{\mathrm{b}}$ & $11(11.8)$ & $I(1.1)$ & $2(2.2)$ & $I(1.1)$ \\
\hline
\end{tabular}

Data from five replicates are pooled.

Values with different superscripts are significantly different $(P<0.05)$

below. All media were filter sterilized. For preincubation $(0.6 \mathrm{ml})$ and insemination $(0.2 \mathrm{ml})$ of spermatozoa, media were placed in the centre of a $35 \mathrm{~mm}$ Petri dish and immediately covered with mineral oil. Media were equilibrated under $5 \%$ $\mathrm{CO}_{2}$ in air for at least $2 \mathrm{~h}$ at $37^{\circ} \mathrm{C}$.

The optimal concentration of spermatozoa was determined in Expt 1 using mKRB medium for preincubation, fertilization and embryo culture. For Expt 2, which examined composition of the media, hypotaurine (Sigma Chemical Co., St Louis, MO) was dissolved in mKRB (without BSA) and the stock solution kept at $100 \mathrm{mmol} \mathrm{l}^{-1}$ at $-20^{\circ} \mathrm{C}$. Medium supplemented with or without $1 \mathrm{mmol}$ hypotaurine $\mathrm{I}^{-1}$ was used for all three IVF phases. BSA (Sigma Chemical Co.) at $4 \mathrm{mg} \mathrm{ml}^{-1}$ or $10 \mathrm{mg} \mathrm{ml}^{-1}$, with or without hypotaurine $\left(1 \mathrm{mmol} \mathrm{l}^{-1}\right)$, was used for all IVF phases during investigation of preincubation of spermatozoa (Expt 3) and timing of in vitro fertilization (Expt 4). The preimplantation development of eggs that remained in the fertilization medium (mKRB with $10 \mathrm{mg} \mathrm{BSA} \mathrm{ml}^{-1}$ and $1 \mathrm{mmol}$ hypotaurine $\mathrm{I}^{-1}$ ) or that were washed and cultured in either $\mathrm{mKRB}$ or pyruvate-free $\mathrm{mKRB}$ with $1 \mathrm{mmol}$ hypotaurine $1^{-1}$ was evaluated in Expt 5.

\section{Egg collection}

Immature female voles (4-6 weeks of age), $20-30 \mathrm{~g}$ body mass, were injected with 30 iu pregnant mares' serum gonadotrophin (PMSG) and $30 \mathrm{iu}$ hCG at a $44 \mathrm{~h}$ interval and killed 14-15 $\mathrm{h}$ after hCG injection. Oviducts were removed, and the ampullae placed in a Petri dish with mineral oil. Eggs with follicular cells were dissected from the ampullae and deposited in $0.2 \mathrm{ml}$ fertilization medium under oil.

\section{Collection, concentration and preincubation of spermatozoa}

Nineteen sexually mature ( 3 months of age) male voles were killed by cervical dislocation. The epididymides were excised and washed in mKRB to remove any traces of blood. After cutting the epididymal ducts with a pair of sharp iridectomy scissors, one to three drops of the dense spermatozoa mass were placed in $0.6 \mathrm{ml}$ medium. The concentration of spermatozoa was determined with a haemocytometer.

For Expt 1, sperm suspensions of $1-2 \times 10^{7}$ or $1-2 \times 10^{8}$ cells $\mathrm{ml}^{-1}$ were preincubated for $2 \mathrm{~h}$ under $5 \% \mathrm{CO}_{2}$ in air at $37^{\circ} \mathrm{C}$. After preincubation, each suspension was added to different Petri dishes that contained eggs in IVF medium, so that the final concentration for insemination was $1 \times 10^{5}$ or

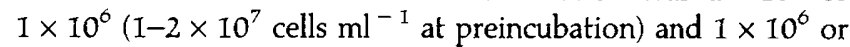
$1 \times 10^{7}$ cells $\mathrm{ml}^{-1}$ ( $1-2 \times 10^{8}$ cells $\mathrm{ml}^{-1}$ at preincubation). Expts 2-5 were conducted with $1-2 \times 10^{7}$ cells ml $^{-1}$ for a $2 \mathrm{~h}$ preincubation and $1 \times 10^{6}$ cells $\mathrm{ml}^{-1}$ for insemination. In Expt 3 , vole spermatozoa were preincubated for $0.5,2$ or $10 \mathrm{~h}$.

\section{Fertilization and development of IVF eggs}

For Expts 1, 2 and 3, eggs and spermatozoa were co-cultured for $6 \mathrm{~h}$ under $5 \% \mathrm{CO}_{2}$ in air at $37^{\circ} \mathrm{C}$, and then eggs were examined for penetration by spermatozoa and pronuclei formation. For Expt 4, eggs were examined 1, 2, 3, 4, 5 or $6 \mathrm{~h}$ after insemination. If eggs incubated for $\mathrm{I}$ and $2 \mathrm{~h}$ contained cumulus cells, these were removed by treatment with $0.1 \%$ $(w / v)$ hyaluronidase. Whole mount egg preparations were examined under a phase-contrast microscope after they were fixed with $2.5 \%(\mathrm{w} / \mathrm{v})$ glutaraldehyde for $2 \mathrm{~h}$ at room temperature and stained with $0.25 \%(\mathrm{v} / \mathrm{v})$ acetolacmoid. Eggs that contained an enlarged sperm head, or one or more male pronuclei with sperm tails and second polar bodies, were judged to be fertilized.

Preimplantation development was examined (Expt 5) by washing some eggs $6 \mathrm{~h}$ after insemination and then placing them in $0.2 \mathrm{ml} \mathrm{mKRB}$ or pyruvate-free $\mathrm{mKRB}$ with $1 \mathrm{mmol}$ hypotaurine $1^{-1}$. The remaining eggs were left in the fertilization medium without washing. All eggs were then cultured under $5 \% \mathrm{CO}_{2}$ in air at $37^{\circ} \mathrm{C}$ for $96 \mathrm{~h}$ after insemination. Development was observed under a dissecting or phasecontrast microscope.

\section{Statistical analysis}

Each experiment was carried out at least four times. The data were analysed by the chi-squared test.

\section{Results}

\section{Effect of concentration of spermatozoa}

As shown in Table 1 , when spermatozoa were preincubated at a high concentration $\left(1 \times 10^{8}\right.$ cells $\left.\mathrm{ml}^{-1}\right)$ and then inseminated at concentrations of $1 \times 10^{7}$ or $1 \times 10^{6}$ cells ml $^{-1}$, 
Table 2. Effect of hypotaurine and BSA in mKRB medium on fertilization of Japanese field vole eggs in vitro

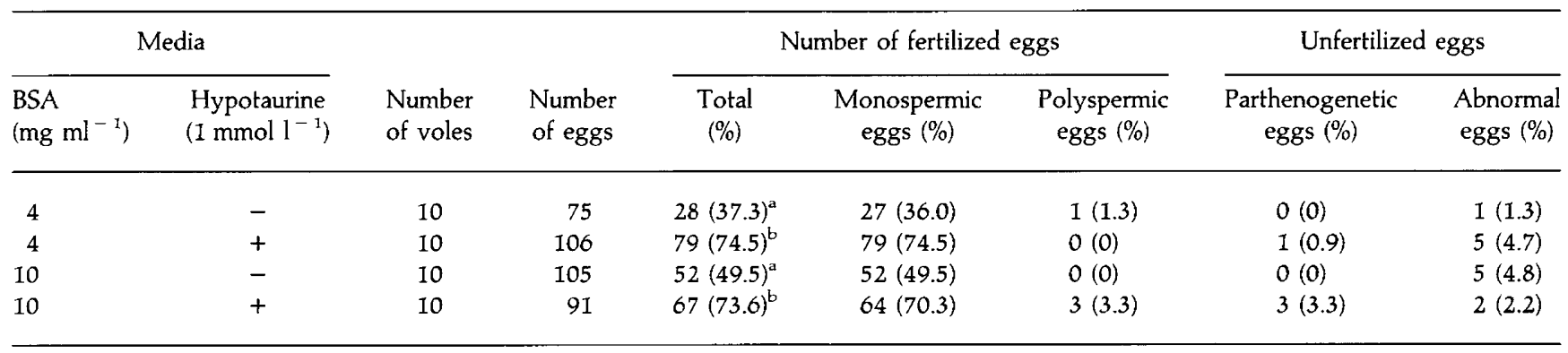

Data from five replicates are pooled.

Values with different superscripts are significantly different $(P<0.05)$.

Table 3. Effect of preincubation time of Japanese field vole spermatozoa on fertilization in vitro

\begin{tabular}{|c|c|c|c|c|c|c|c|}
\hline \multirow{2}{*}{$\begin{array}{l}\text { Preincubation } \\
\quad \text { time of } \\
\text { spermatozoa (h) }\end{array}$} & \multirow[b]{2}{*}{$\begin{array}{l}\text { Number } \\
\text { of voles }\end{array}$} & \multirow[b]{2}{*}{$\begin{array}{l}\text { Number } \\
\text { of eggs }\end{array}$} & \multicolumn{3}{|c|}{ Number of fertilized eggs } & \multicolumn{2}{|c|}{ Unfertilized eggs } \\
\hline & & & $\begin{array}{c}\text { Total } \\
(\%)\end{array}$ & $\begin{array}{c}\text { Monospermic } \\
\text { eggs }(\%)\end{array}$ & $\begin{array}{l}\text { Polyspermic } \\
\text { eggs }(\%)\end{array}$ & $\begin{array}{l}\text { Parthenogenetic } \\
\text { eggs (\%) }\end{array}$ & $\begin{array}{c}\text { Abnormal } \\
\text { eggs (\%) }\end{array}$ \\
\hline 0.5 & 27 & 268 & $185(69.0)^{\mathrm{a}}$ & $180(67.2)$ & $5(1.9)$ & $0(0)$ & $2(0.7)$ \\
\hline 2 & 10 & 140 & $103(73.6)^{\mathrm{a}}$ & $101(72.1)$ & $2(1.4)$ & $2(1.4)$ & $8(5.7)$ \\
\hline
\end{tabular}

Data from five to nine replicates are pooled.

Values with different superscripts are significantly different $(P<0.01)$.

the fertilization rates were very low $(1.0 \%$ and $12.9 \%$, respectively). However, when the concentration was reduced to $1 \times 10^{7}$ cells $\mathrm{ml}^{-1}$ at preincubation and to $1 \times 10^{6}$ or $1 \times 10^{5}$ cells $\mathrm{ml}^{-1}$ at insemination, the fertilization rates were significantly higher at $50.5 \%$ and $43.3 \%$, respectively $(P<0.05)$.

\section{Effect of hypotaurine and BSA}

Inseminating eggs in the presence of hypotaurine significantly increased the fertilization rate $\left(74.5 \%\right.$ in $4 \mathrm{mg} \mathrm{BSA} \mathrm{ml}^{-1}$ in $\mathrm{mKRB}$ and $73.6 \%$ in $10 \mathrm{mg} \mathrm{BSA} \mathrm{ml}^{-1}$ in $\mathrm{mKRB}$ ) compared with that in the absence of hypotaurine $(37.3$ and $49.5 \%$, respectively) (Table 2 ).

\section{Effect of preincubation time}

As shown in Table 3, when spermatozoa were preincubated for 0.5 or $2 \mathrm{~h}$, the fertilization rate was significantly higher $(69.0 \%$ and $73.6 \%$, respectively) than for the $10 \mathrm{~h}$ preincubation $(56.8 \%)$.

In all experiments, the fertilized eggs had one female pronucleus, one or more male pronuclei and penetrating sperm tails (Fig. Ib). The sperm tail was never incorporated inside the vitelline membrane of egg. The percentage of polyspermy was low $(0-5 \%)$. Parthenogenetic eggs with only one pronucleus and without a sperm tail were also rare $(0-3 \%)$.

\section{Time of penetration and fertilization}

Vole sperm penetration of the zona pellucida starts around $2 \mathrm{~h}(8.1 \%)$ and $75 \%$ are penetrated within $4 \mathrm{~h}$ after insemina- tion (Table 4). Decondensation of sperm head(s) commences at about $3 \mathrm{~h}$ (16.9\%; enlarged sperm head; Fig. 1a) and finishes within $6 \mathrm{~h}(86.8 \%$; male and female pronuclei; Fig. Ib) after insemination.

\section{Development in vitro}

As shown in Table 5, most eggs cleaved to the two-cell stage $(76.9-82.6 \%$, Fig. Ic). Although eggs that were washed $6 \mathrm{~h}$ after insemination rarely developed to the four-cell stage in $\mathrm{mKRB}$ and pyruvate-free mKRB medium $(9.6 \%$ and $4.6 \%$, respectively), the non-washed eggs developed to at least the four-cell stage $(60.9 \%, P<0.01)$. In all experiments, a few (1.9-8.7\%) eggs developed to the blastocyst stage (Fig. Id) by $96 \mathrm{~h}$ after insemination.

\section{Discussion}

In the study reported here an IVF technique for Japanese field voles was established. IVF embryos developed to the blastocyst stage in the defined medium. Optimal concentration of spermatozoa and addition of hypotaurine to the medium made vole IVF highly repeatable.

Hypotaurine is found at high concentrations in many tissues, including the male and female reproductive tracts (Van der Horst and Brand, 1969; Van der Horst and Kuipfer, 1972), and in blood serum (Jacobsen and Smith, 1968) and preimplantation embryos (Schultz et al., 1981). Mrsny et al. (1979) and Meizel 

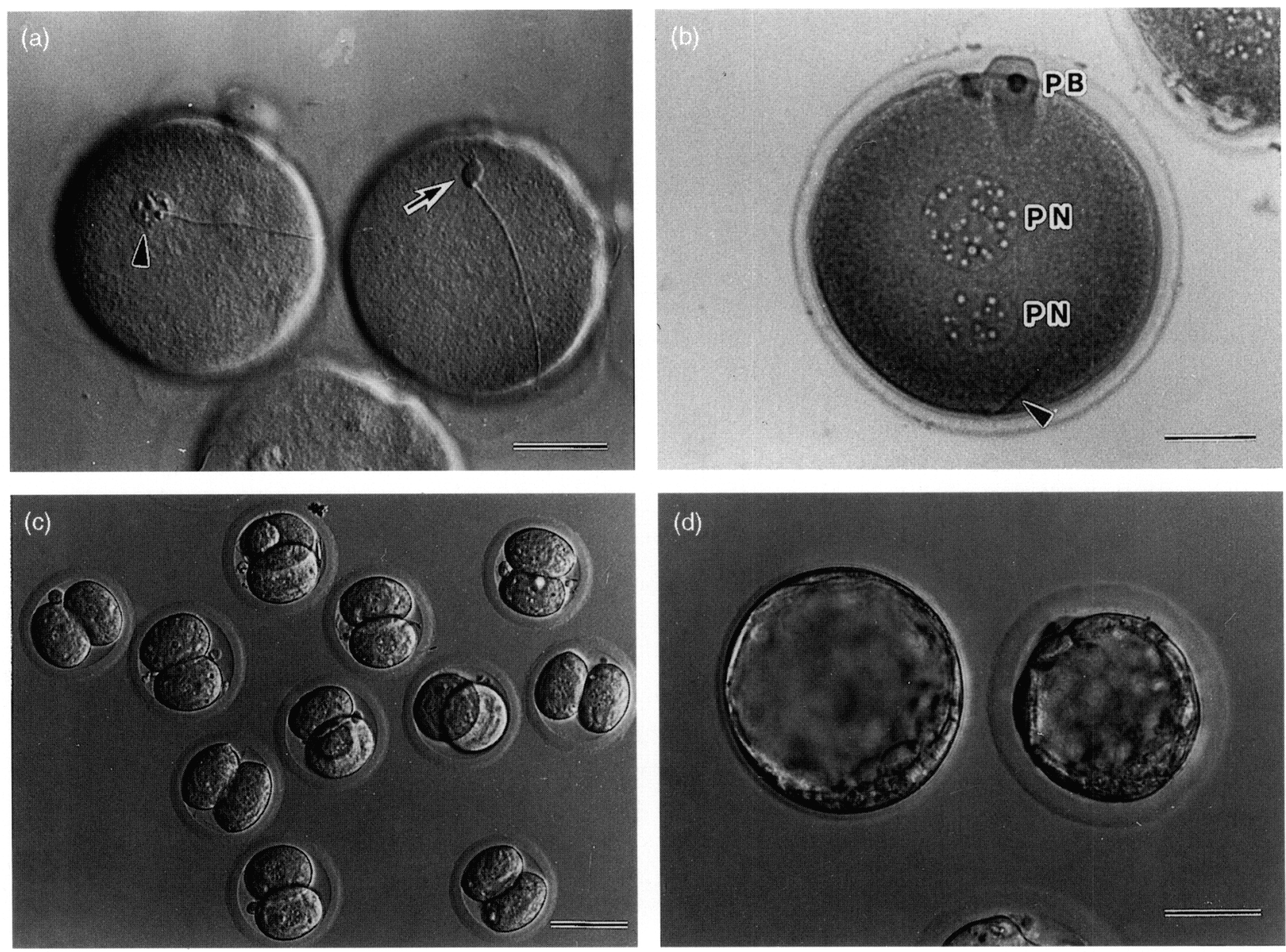

Fig. 1. (a) Enlarged sperm head (arrow) and early male pronucleus (arrowhead) together with corresponding sperm tail in vole eggs cultured for $4 \mathrm{~h}$ after insemination. The sperm tail is not incorporated inside the vitelline membrane of eggs. Scale bar represents $30 \mu \mathrm{m}$. (b) A pronuclear vole egg inseminated in vifro and fixed $6 \mathrm{~h}$ later. The egg has two pronuclei (PN), a sperm tail (arrowhead) and a second polar body (PB). Scale bar represents $20 \mu \mathrm{m}$. (c) Vole embryos at the two-cell stage cultured for $24 \mathrm{~h}$ after insemination. Scale bar represents $60 \mu \mathrm{m}$. (d) Vole embryos at the blastocyst stage cultured for $96 \mathrm{~h}$ after insemination. Scale bar represents $30 \mu \mathrm{m}$.

Table 4. In vitro fertilization by Japanese field vole spermatozoa preincubated for $2 \mathrm{~h}$

\begin{tabular}{lcccccc}
\hline \multirow{2}{*}{$\begin{array}{l}\text { Incubation } \\
\text { time (h) }\end{array}$} & $\begin{array}{c}\text { Number } \\
\text { of eggs }\end{array}$ & $\begin{array}{c}\text { Number }(\%) \\
\text { penetrated }\end{array}$ & Total $(\%)$ & Stage I & Stage II & Polyspermy \\
\cline { 5 - 7 } & 69 & $0(0)$ & $0(0)$ & 0 & 0 & 0 \\
1 & 74 & $6(8.1)$ & $1(1.4)$ & 1 & 0 & 0 \\
2 & 77 & $34(44.2)$ & $13(16.9)$ & 13 & 0 & 2 \\
3 & 84 & $63(75.0)$ & $60(71.4)$ & 22 & 38 & 2 \\
5 & 84 & $73(86.9)$ & $71(84.5)$ & 10 & 01 & 5 \\
6 & 91 & $79(86.8)$ & $79(86.8)$ & 3 & 76 & 5 \\
\hline
\end{tabular}

Data from four replicates are poolcd

Stage l: eggs with enlarged sperm head in vitellus.

Stage II: eggs with male and female pronuclei.

et al. (1980) reported that taurine and hypotaurine may play roles in the maintenance and stimulation of sperm motility and in the stimulation of capacitation and acrosome reactions in vivo.
At a high concentration $\left(1 \times 10^{8}\right.$ cells $\left.\mathrm{ml}^{-1}\right)$, the motility and survival rate of Japanese field vole spermatozoa increased (Wakayama et al., 1993) but the fertilization rate decreased. Even at a low concentration of spermatozoa, a marked 
Table 5. In vitro culture of Japanese field vole IVF eggs

\begin{tabular}{|c|c|c|c|c|c|c|}
\hline \multirow{2}{*}{$\begin{array}{l}\text { Treatment } \\
\text { of embryo }\end{array}$} & \multirow{2}{*}{$\begin{array}{l}\text { Number of } \\
\text { embryos }\end{array}$} & \multicolumn{5}{|c|}{ Conceptus development (\%) } \\
\hline & & $\geq 2$-Cell & $\geq 4$-Cell & $\geq 8$-Cell & $\geq$ Morula & $\geq$ Blastocyst \\
\hline Non-washed & 69 & $57(82.6)$ & $42(60.9)^{\mathrm{a}}$ & $16(23.2)^{\mathrm{a}}$ & $6(8.7)$ & $6(8.7)$ \\
\hline Washed & 52 & $40(76.9)$ & $\begin{array}{ll}5 & (9.6)^{b}\end{array}$ & $3(5.8)^{b}$ & $3(5.8)$ & $3(5.8)$ \\
\hline Washed and PF-mKRB & 65 & $52(80.0)$ & $3(4.6)^{b}$ & $1(1.9)^{b}$ & $1(1.9)$ & $1(1.9)$ \\
\hline
\end{tabular}

Data from four replicates are pooled.

Values with different superscripts are significantly different $(P<0.05)$.

PF-mKRB: pyruvate-free Krebs-Ringer bicarbonate.

improvement in fertilization rate was achieved by addition of hypotaurine to mKRB medium. Therefore, as in hamsters, hypotaurine may act to maintain and stimulate the motility and capacitation of spermatozoa in field voles.

In general, preincubated spermatozoa undergo capacitation in culture medium, although the time required for capacitation varies among species. For example, $1-2 \mathrm{~h}$ is required for mouse spermatozoa (Toyoda et al, 1971), $2.5 \mathrm{~h}$ for hamsters (Yanagimachi, 1970), 5-7 h for rats (Niwa and Chang, 1974), and 8-12 h for guinea-pigs (Yanagimachi, 1972). In the study reported here, vole spermatozoa preincubated for $0.5 \mathrm{~h}$ penetrated vole eggs and male pronuclei were formed $6 \mathrm{~h}$ after insemination. However, vole spermatozoa preincubated for $2 \mathrm{~h}$ could penetrate the zona pellucida within $2 \mathrm{~h}$ after insemination and completely formed male pronuclei $6 \mathrm{~h}$ after insemination. It is suggested that vole epididymal spermatozoa require a very short period of preincubation for capacitation when the sperm concentration is $1 \times 10^{6} \mathrm{cells} \mathrm{ml}^{-1}$.

Rabbits exhibit a copulatory ovulation and their ovulation occurs within $10 \mathrm{~h}$ after mating. Rabbit epididymal spermatozoa require $10 \mathrm{~h}$ for capacitation in a defined medium (Hosoi et al., 1981; Niwa et al., 1983). Although cats also exhibit induced ovulation and ovulate at $24-28 \mathrm{~h}$ after mating (Greulich, 1934), the capacitation time is short for spermatozoa in the ductus deferens and epididymis (Bowen, 1977; Niwa et al., 1985). In Japanese field voles, ovulation occurs within $12 \mathrm{~h}$ after mating; however, the sperm capacitation time is as short as in cats. It is not clear why the required time for capacitation in voles is so short when compared with the period between mating and ovulation.

Japanese field vole embryos can be cultured from the late two-cell to blastocyst stage $(64 \%)$ using Mi6 medium (Whittingham, 1971). Although most one- and early two-cell embryos did not develop to the blastocyst stage (2 and $14 \%$, respectively), early two-cell embryos cultured in pyruvate-free M16 developed to blastocysts at a significantly higher rate $(42 \%, P<0.05$, Wakayama et al., 1994). In the present study, IVF vole eggs developed to the two-cell stage in mKRB medium with hypotaurine (76.9-82.6\%), but eggs that were washed after insemination developed to the four-cell stage at very low rates in mKRB and pyruvate-free mKRB media $(9.6$ and $4.6 \%$, respectively). However, when the IVF eggs were cultured with inseminating spermatozoa for $96 \mathrm{~h}$ without washing, the development rate to the four- and eight-cell stages was significantly higher $(60.6 \%$ and $23.2 \%$, respectively, $P<0.01$ ), although the rate of development to the blastocyst stage remained very low $(8.7 \%)$. Because few differences are found in M16 and mKRB medium, vole embryos might be affected by washing. Although Barmett and Bavister (1992) and Reed et al. (1992) reported that hamster and pig embryos require hypotaurine for in vitro development, this does not appear to be the case in vole embryos.

Japanese field vole eggs can be fertilized and cultured in vitro as easily as those of rats and hamsters. Therefore, they may become a useful experimental model for reproductive and developmental biology.

\section{References}

Barmett DK and Bavister BD (1992) Hypotaurine requirement for in vitro development of golden hamster one-cell embryos into morulae and blastocysts, and production of term offspring from in vitro-fertilized ova Biology of Reproduction 47 297-304

Bowen RA (1977) Fertilization in vitro of feline ova by spermatozoa from the ductus deferens Biology of Reproduction 17 144-147

Goto N and Hashizume R (1978) Pattern of ovulation in Microtus montebelli Journal of the Mammalogical Society of Japan 7 181-189 (in Japanese with English summary)

Goto N, Hashizume R and Sai I (1977) Litter size and vaginal smear in Microtus montebelli Journal of the Mammalogical Society of Japan 7 75-85 (in Japanese with English summary)

Greulich WW (1934) Artificially induced ovulation in the cat (Felis domestica) Anatomical Record 58 217-224

Hosoi Y, Niwa S, Hatanaka S and Iritani A (1981) Fertilization in vitro of rabbit eggs by epididymal spermatozoa capacitated in a chemically defined medium Biology of Reproduction 24 637-642

Imai S and Ogimoto K (1988) Flagellate protozoa in the digestive tract of the Japanese field vole, Microtus montebelli Japanese Journal of Zootechnical Science $59351-356$

Jacobsen JG and Smith LH Jr (1968) Biochemistry and physiology of taurine and taurine derivatives Physiological Reviews 48 424-511

Kudo H and Oki Y (1984) Microtus species as new herbivorous laboratory animals: reproduction; bacterial flora and fermentation in the digestive tracts; and nutritional physiology Veterinary Research Communications 8 77-91

Meizel S, Lui CW, Working PK and Mrsny RJ (1980) Taurine and hypotaurine: their effects on motility, capacitation and the acrosome reaction of hamster sperm in vitro and their presence in sperm and reproductive tract fluids of several mammals Development Growth and Differentiation 22 483-494

Mrsny RJ, Waxman L and Meizel S (1979) Taurine maintains and stimulates motility of hamster sperm during capacitation in vitro Journal of Experimental Zoology 210 123-128

Niwa K and Chang MC (1974) Optimal sperm concentration and minimal number of spermatozoa for fertilization in vitro of rat eggs Journal of Reproduction and Fertility $40471-474$

Niwa K, Hosoi Y, Ohara K and Iritani A (1983) Fertilization in vitro of rabbit eggs with or without follicular cells by epididymal spermatozoa capacitated in a chemically defined medium Animal Reproduction Science 6 143-149 
Niwa K, Ohara K, Hosoi Y and Iritani A (1985) Early events of in-vitro fertilization of cat eggs by epididymal spermatozoa Journal of Reproduction and Fertility $74657-660$

Reed ML, Illera MJ and Petters RM (1992) In vitro culture of pig embryos Theriogenology 37 95-109

Schultz GA, Kaye PL, McKay DJ and Johnson MH (1981) Endogenous aminoacid pool sizes in mouse eggs and preimplantation embryos journal of Reproduction and Fertility 61 387--393

Toyoda Y and Chang MC (1974) Fertilization of rat eggs in vitro by epididymal spermatozoa and the development of eggs following transfer Joumal of Reproduction and Fertility 36 9-22

Toyoda Y, Yokoyama M and Hoshi T (1971) Studies on the fertilization of mouse eggs in vitro. 2 . Effects of in vitro pre-incubation of spermatozoa on time of sperm penetration of mouse eggs in vitro Japanese Journal of Animal Reproduction 16 152-157

Van Der Horst CJG and Brand A (1969) Occurrence of hypotaurine and inositol in the reproductive tract of the ewe and its regulation by pregnenolone and progesterone Nature $22367-68$
Van Der Horst CJG and Kuipfer CJ (1972) Investigation into the occurrence of some steroids, amino acids and carbohydrates on specific days of the oestrous cycle of the pig Netherlands Journal of Veterinary Science 5 35-46

Wakayama T, Maruyama Y, Imamura K and Fukuta K (1993) Penetration of the zona pellucida of eggs of different species by spermatozoa of the Japanese field vole, Microtus montebelli Joumal of Reproduction and Development 39 319-323

Wakayama T, Matubara Y, Imamura K, Kurohmaru M, Hayashi Y and Fukuta K (1994) Development of early-stage embryos of the Japanese field vole, Microtus montebelli, in vivo and in vitro Journal of Reproduction and Fertility $101663-666$

Whittingham DG (1971) Culture of mouse ova Journal of Reproduction and Fertility Supplement 14 7-21

Yanagimachi R (1970) In vitro capacitation of golden hamster spermatozoa by homologous and heterologous blood sera Biology of Reproduction 3 147-153

Yanagimachi R (1972) Fertilization of guinea pig eggs in vitro The Anatomical Record 174 9-20 